Jurnal Ilmu Komunikasi UHO : Jurnal Penelitian Kajian Ilmu Komunikasi dan Informasi.

Volume 6, No. 1, Januari 2021, hlm 59-66

\title{
KOMUNIKASI INTERPERSONAL MAHASISWA FISIP MELALUI PENGGUNAAN APLIKASI DATING TANTAN
}

\author{
Jumi Fitri Untung ${ }^{1}$, Sumadi Dilla ${ }^{2}$, Sutiyana Fachruddin ${ }^{3}$ \\ ${ }^{123}$ Fakultas Ilmu Sosial dan Ilmu Politik, Universitas Halu Oleo \\ Kampus Hijau Bumi Tridharma Anduonohu, Kendari, Indonesia \\ Jumifitri78@gmail.com
}

\begin{abstract}
ABSTRAK
Proses komunikasi dilakukan lebih bebas, praktis, dan terbuka membuat pemilihan jodoh dapat berkembang dengan adanya media pencarian jodoh, antara lain aplikasi pencarian jodoh yang memberikan peluang yang sama antara perempuan dan laki-laki untuk memilih pasangan yang diidamkan. Proses komunikasi yang terjadi dalam aplikasi ini bersifat interpersonal dengan sistem swip e and match memudahkan mereka memilih ketika sudah memiliki ketertarikan. Bertemu dengan orang - orang baru untuk membina suatu hubungan yang berawal dari komunikasi interpersonal. penelitian ini memfokuskan membahas tentang bentuk hubungan interpersonal yang terbentuk melalui penggunaan aplikasi dating tantan, studi ini menggunakan data-data kualitatif dengan menggunakan teori penggunaan dan kepuasan oleh Katz,Blumer,dan Gurevtich. Penentuan Informan berjumlah sepuluh orang yang dipilih dengan pertimbangan dan tujuan tertentu, hasil dari penelitian ini hubungan intrpersonal yang terbentuk melalui tiga tahapun yaitu kenalan, pertemanan, dan hubungan pribadi, hadirnya aplikasi jodoh tentunya memberikan dampak bagi para pengguna untuk itu pengguna disarankan untuk lebih berhati-hati dalam menggunakan aplikasi jodoh dalam mencari teman ataupun pasangan.
\end{abstract}

Kata-kata Kunci: Aplikasi Tantan; Pencarian Jodoh; Kencan; Komunikasi; Media Baru 
Jurnal Ilmu Komunikasi UHO : Jurnal Penelitian Kajian Ilmu Komunikasi dan Informasi.

Volume 6, No. 1, Januari 2021, hlm 59-66

\title{
KOMUNIKASI INTERPERSONAL MAHASISWA FISIP MELALUI PENGGUNAAN APLIKASI DATING TANTAN
}

\begin{abstract}
The communication process is carried out more freely, practically, and openly so that mate selection can develop with matchmaking media, including matchmaking applications that provide equal opportunities between women and men to choose the desired partner. The communication process that occurs in this application is interpersonal with the swip e and match system, making it easy for them to choose when they already have an interest. Meet new people to foster a relationship that starts with interpersonal communication. This study focuses on discussing the form of interpersonal relationships that are formed through the use of male dating applications, this study uses qualitative data using theories of use and satisfaction by Katz, Blumer, and Gurevtich. Determination of informants totaling ten people selected with specific considerations and objectives, the results of this study intrpersonal relationships formed through three years, namely acquaintance, friendship, and personal relationships, the presence of matchmaking applications certainly have an impact on the users for that users are advised to be more careful careful in using a match application in finding friends or partners.
\end{abstract}

Keywords: Tantan application;Matchmaking;Dating;Communication;New Media 
Jurnal Ilmu Komunikasi UHO : Jurnal Penelitian Kajian Ilmu Komunikasi dan Informasi.

Volume 6, No. 1, Januari 2021, hlm 59-66

\section{PENDAHULUAN}

Percakapan menggunakan aplikasi chatting adalah aktivitas berkomunikasi sehari-hari yang paling populer digunakan oleh pengguna internet saat ini. Dampak dari inovasi aplikasi ini adalah terjadinya perubahan cara berkomunikasi, perubahan gaya hidup dan cara pemenuhan kebutuhan manusia. Perubahan yang paling menonjol terjadi pada perilaku percakapan sehari - hari yang sebagian besar dapat dijumpai pada aplikasi chatting, seperti aplikasi chatting sekaligus dating. Proses komunikasi dilakukan lebih bebas, praktis, dan terbuka membuat pemilihan jodoh dapat berkembang dengan adanya media pencarian jodoh, antara lain aplikasi pencarian jodoh yang memberikan peluang yang sama antara perempuan dan laki-laki untuk memilih pasangan yang diidamkan.

Saat ini anak-anak muda lebih terbuka mengungkapkan perasaan dan tidak lagi harus memakai perantara atau juru bicara, sebagian besar pengguna aplikasi jodoh adalah kalangan mahasiswa, salah satunya mahasiswa Fakultas Ilmu Sosial dan Ilmu Politik. Salah satu aplikasi jodoh yang tengah tenar dan populer saat ini adalah aplikasi Tantan. Pada Tahun 2019 Aplikasi Tantan telah tersedia di 87 negara dengan total pengguna mencapai lebih dari 213 juta, dengan memiliki 60 juta pengguna tervalidasi dan mendapat keuntungan berjumlah $\$ 70$ juta, Aplikasi kencan Tiongkok ini, mengklaim telah mengalami pertumbuhan jumlah pengguna di karenakan Tantan menawarkan platform yang menjamin data diri dari pengguna aplikasi Tantan terus merambah ke India dan Asia Tenggara termasuk Indonesia. Aplikasi Tantan masuk ke Indonesia pada bulan Juli tahun 2018 dan pada saat itu Indonesia menjadi pengguna terbanyak aplikasi Tantan dan hingga saat ini pengguna aplikasi Tantan di Indonesia mencapai 10 juta lebih pengguna dan pastinya akan terus meningkat dengan melakukan promosi dibeberapa acara televisi dan endorsement yang merupakan cara promosi yang sedang banyak digunakan saat ini.

Fenomena penggunaan aplikasi jodoh di kalangan mahasiswa FISIP ini, merupakan sesuatu hal yang baru dan menarik untuk diketahui, alasan mereka menggunakan aplikasi tersebut. Dalam mencapai hubungan interpersonal hendaknya komunikasi berlangsung secara terus - menerus sehingga terjadi proses kedekatan hubungan interpersonal dalam aplikasi Tantan tersebut. Berdasarkan realitas latar belakang tersebut maka rumusan masalah dalam penelitian ini adalah apa saja bentuk hubungan interpersonal yang terbentuk melalui penggunaan aplikasi dating tantan serta tujuan penelitian adalah untuk mengetahui apa saja bentuk hubungan interpersonal yang terbentuk melalui penggunaan aplikasi dating Tantan. 
Jurnal Ilmu Komunikasi UHO : Jurnal Penelitian Kajian Ilmu Komunikasi dan Informasi.

Volume 6, No. 1, Januari 2021, hlm 59-66

Penelitian ini memfokuskan membahas tentang bentuk hubungan interpersonal yang terbentuk melalui penggunaan aplikasi dating tantan, Adapun manfaat dari tulisan ini adalah hasil penelitian ini nantinya diharapkan dapat memberikan kontribusi pada beberapa aspek, yaitu aspek teoritis, dapat memberi gambaran tentang komunikasi interpersonal mahasiswa FISIP melalui penggunaan aplikasi dating Tantan sehingga dapat menjadi sumbangan bagi pengembangan ilmu pengetahuan khususnya komunikasi interpersonal dan menambah kajian media baru dan perilaku sosial.

Aspek metedologis penelitian ini dapat dimanfaatkan sebagai sumber informasi untuk peneliti selanjutnya dalam menyusun penelitian guna melihat komunikasi interpersonal mahasiswa FISIP melalui penggunaan aplikasi dating Tantan, dan aspek praktis penelitiaan ini dapat dimanfaatkan oleh berbagai kalangan baik pemerintah, mahasiswa, maupun masyarakat umum, dalam melihat komunikasi interpersonal mahasiswa FISIP melalui penggunaan aplikasi dating Tantan.

Teori penggunaan dan kepuasan atau uses and gratifications yang dikemukakan oleh Katz, Blumler, dan Gurevitch (1973) asumsi dasarnya setiap orang berhak memilih mana media yang dapat memenuhi kebutuhannya. dianggap sebagai salah satu teori yang mencoba menjelaskan bagaimana individu media. Teori ini mengemukakan bahwa setiap individu memiliki perbedaan dalam menggunakan, mencari, dan memberikan umpan balik terhadap isi media secara berbeda-beda.

Dalam aplikasi ini ditawarkan fitur-fitur yang memugkinkan penggunanya berbagi pesan, gambar, dan video, dari penggunaan fitur tersebut dapat dilihat motif mendalam penggunaan aplikasi dating Tantan ini, dari proses komunikasi interpersonal yang terjadi antar sesama pengguna aplikasi Tantan sehingga ada bentuk hubungan interpersonal yang terjalin setelah penggunaan aplikasi dating tantan tersebut.

\section{METODE PENELITIAN}

Data yang digunakan dalam penelitian ini adalah data kualitatif yaitu data yang berupa keterangan atau penjelasan tentang hal-hal yang berhubungan dengan komunikasi interpersonal mahasiswa FISIP melalui peggunaan aplikasi dating Tantan. Penelitian kualitatif adalah penelitian yang bersifat deskriptif dan memfokuskan pada pemahaman mendalam mengenai suatu masalah. Subjek penelitian ini adalah mahasiswa Fakultas Ilmu Sosial dan Ilmu Politik Universitas Halu Oleo yang terdiri dari dua jurusan Ilmu Komunikasi dan Sosiologi yang dianggap kredibel untuk menjawab pertanyaan. 
Jurnal Ilmu Komunikasi UHO : Jurnal Penelitian Kajian Ilmu Komunikasi dan Informasi.

Volume 6, No. 1, Januari 2021, hlm 59-66

Teknik pengumpulan data dan informasi merupakan cara yang dilakukan dalam rangka mencapai tujuan. Teknik pengumpulan data yang di lakukan yaitu observasi, pada penelitian ini observasi dilakukan dengan cara mengamati perilaku individu dalam menggunakan aplikasi dating tersebut melalui akun - akun Tantan yang dimiliki. Wawancara pada penelitian ini wawancara yang dilaksanakan dengan informan adalah wawancara testruktur dimana, dengan menggunakan daftar pertanyaan yang jelas berkaitan dengan tanggapan mereka penggunaan aplikasi Tantan dalam membentuk hubungan interpersonal.

Studi Kepustakaan, yaitu data-data diperoleh dengan menghimpun informasi dari buku - buku, jurnal penelitian, tesis dan disertasi baik tercetak maupun elektronik yang relevan terhadap topik atau masalah di teliti. Dokumentasi yaitu data-data penelitian yang berupa gambar/potret untuk memperkuat data-data wawancara. Data yang di peroleh dalam laporan ini dianalisis dengan menggunakan analisis deskriptif kualitatif yakni dengan menjelaskan kenyataan sehubungan dengan permasalahan yang dianalisis yang diperoleh dari lapangan secara jelas yang pada akhirnya dapat ditarik sebuah kesimpulan.

\section{HASIL DAN PEMBAHASAN}

Berdasarkan penelitian yang dilakukan kesepuluh orang informan yang peneliti, yang merupakan mahasiswa jurusan Ilmu Komunikasi dan Sosiologi yang berusia 21-23 tahun dengan kriteria-kriteria yang sesuai dengan tujuan penelitian. ditemukan hasil penelitian yang sesuai dengan tiga indikator struktur analisis peneliti bahwa informan penelitian yaitu pengguna aplikasi dating tantan membentuk hubungan interpersonal melalui aplikasi tantan dari tiga indikator penelitian penulis yaitu perkenalan, pertemanan, dan hubungan pribadi. Sehingga penulis mengelompokkan jawaban dari informan penulis menjadi hubungan perkenalan yang terjadi yaitu bentuk hubungan interpersonal.

Informan penulis mengemukakan tahap-tahap proses komunikasi yang mereka lakukan diawali. pertama perkenalan, pengguna berkenalan dengan orang baru baik di dalam maupun luar negeri. Kedua pertemanan, pengguna menjalin hubungan teman akrab, teman kencan, dan teman chattingan melalui aplikasi tantan. Ketiga hubungan pribadi yang terjalin melalui aplikasi tantan yaitu pacaran dan long distance relationship.

Berdasarkan teori uses and gratifications Katz, Blumer, dan Gurevtich (1973) yang asumsi dasarnya setiap orang berhak memilih mana media yang dapat memenuhi kebutuhannya. Dapat dianggap sebagai salah satu teori yang mencoba menjelaskan bagaimana individu media yang didasarkan pada motif dan penggunaan aplikasi tantan. Dari 
Jurnal Ilmu Komunikasi UHO : Jurnal Penelitian Kajian Ilmu Komunikasi dan Informasi.

Volume 6, No. 1, Januari 2021, hlm 59-66

hasil penelitian penulis pengguna memenuhi motif penggunaan yang ada dalam teori tersebut dan merasa terpuaskan menggunakan aplikasi tersebut sebagai aplikasi sosial untuk mengenal orang lain. Perbedaan motif ataupun kepuasan yang dirasakan pengguna disebabkan oleh adanya berbagai faktor sosial dan psikologis yang berbeda-beda. Dari hasil wawancara mengenai komunikasi interpersonal mahasiswa FISIP melalui penggunaan aplikasi dating tantan, pengguna aplikasi tantan di dapatkan fakta di lapangan bahwa kemampuan aplikasi tantan untuk memberikan kemudahan pengguna untuk bertemu dengan orang baru dengan mudah dikatakan berhasil, hal ini terbukti dari jalinan komunikasi antar pribadi yang terjadi antara sesama pengguna, mereka akan memilih seperti apa mereka menjalani hubungan setelah mengenal melalui aplikasi ini.

Menurut Mark Knapp beberapa tahapan hubungan interpersonal yang dilalui salah satunya tahap perkenalan atau inisiasi adalah tahap awal yang dicirikan dengan sedikit pembicaraan dan masuk tahap eksperimen suatu tahap dimana para individual mulai mencari informasi lebih banyak tentang individu lain, dua tahapan ini sesuai dengan tahap perkenalan. Informan yang penulis wawancarai banyak yang merasakan tahapan hubungan yang sampai perkenalan saja sehingga mereka tidak melanjutkan obrolan ketika sudah mengetahui informasi masing-masing.

Tahap kedua adalah pertemanan tahap hubungan lanjutan dari proses kenalan yang terjadi hanya satu pengguna saja yang menjalin hubungan pertemanan dengan pengguna yang ditemuinya, sulitnya menjalin hubungan pertemanan dengan melalui media sosial menjadi alasan utamanya. Menurut Mark Knapp tahapan ini masuk dalam tahapan intesifikasi yaitu individu harus memutuskan baik secara verbal maupun non verbal hubungan akan dilanjutkan atau tidak.

Jenis hubungan interpersonal yang ketiga adalah hubungan pribadi tahapan hubungan dimana individu secara formal meneguhkan hubungan mereka, semua informan yang penulis wawancarai utamanya pengguna wanita pernah menjalin hubungan pribadi dengan pengguna tantan tetapi dengan jangka waktu yang singkat sehingga mereka berganti-ganti pasangan dengan mudah. Sedangkan laki-laki tidak berniat mencari hubungan pribadi dengan pengguna tantan mereka hanya sebatas menjalin hubungan pertemanan dalam artian teman kencan.

Adanya perbedaan jalinan hubungan interpersonal yang terjadi antara pengguna aplikasi tantan laki-laki dan perempuan, laki-laki yang hanya menjalin hubungan interpersonal sampai hubungan sampai teman kencan saja, sedangkan perempuan menjalin 
Jurnal Ilmu Komunikasi UHO : Jurnal Penelitian Kajian Ilmu Komunikasi dan Informasi.

Volume 6, No. 1, Januari 2021, hlm 59-66

hubungan interpersonal sampai hubungan pribadi. Hadirnya aplikasi tantan sebagai akibat dari hadirnya media baru, pemilihan dan penggunaan aplikasi tantan di tengah banyaknya aplikasi jodoh yang hadir dimasyarakat diawali dari motif mereka dalam menggunakan aplikasi tantan sehingga terbentuk hubungan interpersonal sesama penggunanya.

Bentuk hubungan interpersonal yang terjalin sebagai akibat dari penggunaan aplikasi tantan pada mahasiswa FISIP sebagai media pencarian jodoh, Jika di tinjau menggunakan teori uses and gratifications atau teori penggunaan dan kepuasan dari Katz, Blumer, and Gurevtich dianggap memiliki keterkaitan karena tantan merupakan salah satu media baru yang muncul dan menawarkan aplikasi biro jodoh ditengah banyaknya aplikasi jodoh yang bermunculan sebagai dampak hadirnya media baru.

Penggunaan aplikasi jodoh dikalangan mahasiswa FISIP digunakan karena dalam proses pencarian pacar, teman, atau jodoh melalui aplikasi tantan. Yang dulunya pencarian jodoh atau pasangan dengan cara diperkenalkan oleh teman maupun orang tua, namun dengan munculnya media tantan memudahkan pengguna untuk berinteraksi dengan orang baru dan memilih sesuai kriteria pengguna masing-masing.

\section{SIMPULAN}

Pengguna aplikasi tantan membentuk hubungan interpersonal dari tiga indikator jenis hubungan interpersonal yaitu Perkenalan, yaitu pengguna berkenalan dengan orang baru dari dalam negeri maupun luar negeri melalui aplikasi tantan. Pertemanan, yaitu seperti memiliki kenyamanan untuk berkomuikasi cukup intens dan saling bertukar pendapat sehingga hubungan pertemanan yang terbentuk adalah teman akrab, teman chattingan, dan teman kencan. Hubungan pribadi hasil dari proses komunikasi yang dilakukan seperti melakukan komunikasi yang lebih intens, memastikan hubungan mereka untuk berpacaran dan long distance relationship (LDR). Dalam mencapai hubungan pribadi ataupun pertemanan semua berawal dari hubungan perkenalan antar sesama penggunanya sehingga mereka bisa menentukan kepastian dan kelanjutan hubungannya. Berdasarkan hasil penelitian tersebut maka penulis menyarankan pengguna yang menggunakan aplikasi jodoh untuk memberikan image yang baik untuk aplikasi tantan, dengan sebaiknya memanfaatkan fungsi aplikasi tantan dengan baik sebagai sarana aplikasi sosial untuk mengenal orang lain, berinteraksi dengan orang baru, dan mencari pasangan yang di inginkan, dan pengguna aplikasi tantan perempuan untuk lebih berhati-hati mencari pasangan melalui aplikasi tantan demi keamanan diri masing-masing pengguna aplikasi jodoh. 
Jurnal Ilmu Komunikasi UHO : Jurnal Penelitian Kajian Ilmu Komunikasi dan Informasi.

Volume 6, No. 1, Januari 2021, hlm 59-66

\section{DAFTAR PUSTAKA}

\section{Buku :}

Adi, Rianto. (2004). Metedologi Penelitian Sosial Dan Hukum. Jakarta: Granit

Briggs, Asa \& Bukke Peter. (2006) Sejarah Asal Usul Sosial Media. Jakarta: Yayasan Obor Indonesia.

Budyatna, Muhammad \& Ganiem, Leila Mona. (2011). Teori Komunikasi Antarpribadi. Jakarta: Kencana Prenada Media Group

Cangara, Hafied. (2014) Pengantar Ilmu Komunikasi. Jakarta: Raja Grafindo Persada

Cangaara, Hafied. (2014). Perencanaan \& Strategi Komunikasi. Jakarta: Raja Grafindo Persada.

Djamaluddin, Dedy \& Iriantara, Yosal. (2004). Komunikasi Persuasif. Bandung: Remaja Rosdakarya

Fajar, M. (2009). Ilmu Komunikasi: Teori dan Praktik. Yogyakarta: Graha Ilmu.

Fiske, John. (2014). Pengantar Ilmu Komunikasi. Jakarta: Raja Grafindo Persada

Lunandi, A.G. (1994). Komunikasi Mengenai: Meningkatkan Efektivitas Komunikasi Antar Pribadi.

Yogyakarta: Kanisius

Mulyana, D. (2002). Ilmu Komunikasi, Suatu Pengantar. Bandung: PT. Remaja Rosdakarya

Nasrullah, Rulli. (2014). Teori dan Riset Media Cyber. Jakarta: Kencana Prenada Media Group

Harapan, Edi \& Ahmad, H Syarwani. (2014). Komunikasi Antarpribadi. Jakarta: Raja Grafindo

Persada

Herdiansyah, Haris. (2013). Wawancara, Observasi, Dan Focus Groups. Jakarta: Raja Grafindo Persada.

Smith, Jonathan A. (2009). Psikologi Kualitatif: Panduan Praktis Metode Riset. Yogyakarta: Pustaka Pelajar

Soyomukti, Nurani. (2010). Pengantar Ilmu Komunikasi. Yogyakarta: Ar-Ruzz Media

Sugiyono. (2011). Metode Penelitian Kualitatif. Bandung: Alfabeta

Umar, Husein. (2014). Metode Penelitian Untuk Skripsi Dan Tesis Bisnis. Jakarta: Raja Grafindo Persada

\section{Jurnal Online:}

Dian Maria Manalu. (2014). Komunikasi Antarpribadi Melalui Media Sosial Skype Pada Mahasiswa Universitas Riau. Diakses 23 desember 2018

Nurul Huda Nasution. (2012). Self Disclouser dan Media Komunikasi. Diakses 23 desember 2018 Rahmita Saleh. (2018). Pola Komunikasi Pengguna Aplikasi Chatting. Diakses 23 desember 2018

Totok Wahyu Abadi. (2018). Media Sosial dan Pengembangan Hubungan Interpersonal. Diakses 23 desember 2018

M. Fachri Syahreza. (2018), S . Motif dan Pola Penggunaan Media Sosial Instagram Di Kalangan Mahasiswa. Diakses 9 september 2019 